\title{
Conflict Resolution in the Niger Delta Region of Nigeria: An Empirical Investigation
}

\author{
Onibere, E. A ${ }^{1}$ \\ Egbokhare, F. $\mathbf{A}^{2}$ \\ Ekong, V. E ${ }^{3}$ \\ Amadin F. I $^{4}$ \\ ${ }^{1,2,4}$ Department of Computer Science \\ University of Benin \\ Benin City \\ Nigeria \\ ${ }^{3}$ Department of Computer Science \\ University of Uyo \\ Nigeria
}

\begin{abstract}
This study investigated conflicts in the Niger Delta region of Nigeria which is triggered by prolonged socioeconomic and political alienation marked by extreme poverty, hunger, disease, environmental pollution and high levels of youth unemployment. The region has witnessed an unprecedented spate of violent conflicts in the recent past, and all efforts to quell it seem to have defied solutions. In this study, we obtained unstructured and structured data from indigenes of the Niger Delta oil producing communities, oil exploration and oil-based organizations operating in the region and the Niger Delta Development Commission (NDDC) on the projects sited so far, the criteria used, causes of conflicts and current methods of resolution. The results of the findings provided insights on the current reality of conflict in the region by identifying a number of political, socioeconomic, and environmental risk factors as central to conflict escalation as well as measures to curb them.
\end{abstract}

Keywords: Conflicts, Conflict Resolution, Dialogue, Niger Delta, Prevention

\section{Introduction}

The Niger Delta region is made up of nine of Nigeria's thirty-six states namely: Abia, Akwa Ibom, Bayelsa, Cross River, Delta, Edo, Imo, Ondo and Rivers state. Located in the south-south zone of the country (See Figure 1), it is the region that produces oil - the lifeline of the Nigerian economy, as oil provides $95 \%$ of Nigeria's foreign exchange earnings and $80 \%$ of the government's budgetary revenues (Ajodo-Adebanjoko, 2017). According to the Nigerian National Petroleum Company (NNPC), Nigeria's oil production accounts for 8\% of the Organization of Petroleum Exporting Corporation's (OPEC) total daily production and 3\% of the world's volume. The oil and gas resources are operated by multinational firms such as Shell, Exxon Mobil, Chevron, Elf, Agip and Texaco, in joint venture with the Nigerian National Petroleum Company (Ajodo-Adebanjoko, 2017; Okoh, 2005).

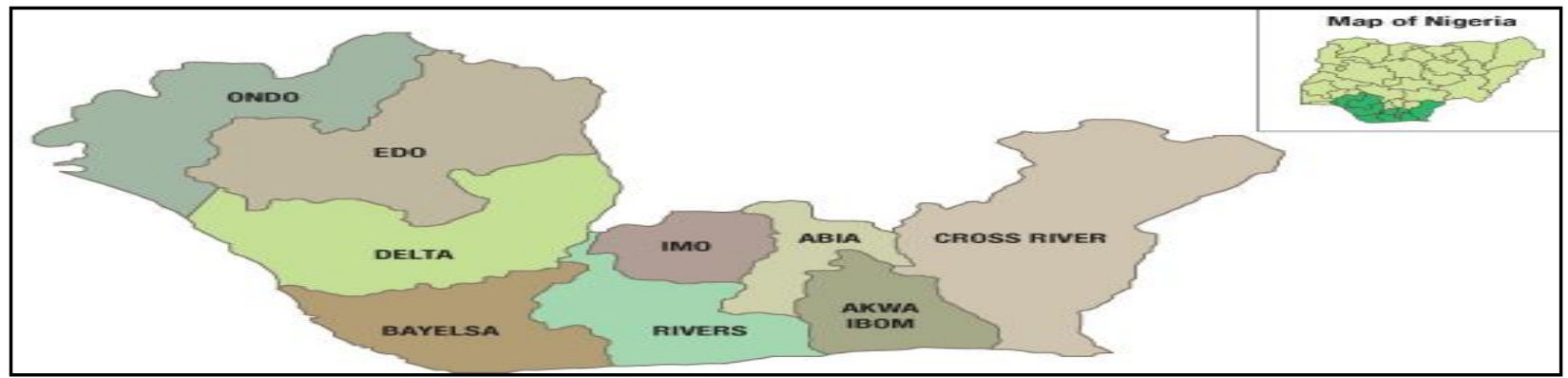

Figure 1: Map of Nigeria showing the Niger Delta states 
Many years of oil and gas exploration and production with frequent occurrence of crude oil and petroleum product spillages have left the people of the region dispossessed of their land, land fertility, delta forest, water resources and their livelihood. These losses have led to high levels of poverty and unemployment (particularly among youths), infrastructure decay, water and air pollution, moral decadence and crime in the area. The area has been denied the much needed development of social and economic infrastructure such as electricity, roads, pipe borne water and adequate healthcare facilities. The Niger Delta states suffer from relatively high rates of both rural and urban unemployment. From year 2000, the Nigerian government stepped up the proportion of revenue shared to the Niger Delta states and infrastructure development tended to improve through the activities of the NDDC, but the levels of poverty, unemployment and violent conflicts are still high. In addition, the insensitivity of major oil producing companies towards the plight of the Niger Delta communities has continued to overshadow the little good done by them through employment opportunities, provision of healthcare facilities and other corporate social responsibility programmes (Omotosho, 2013). Omofunma and Odia (2009) had earlier termed these efforts as 'tokenistic' as the communities view them as paltry when compared to the perceived value of resource exploitation by the oil companies and the Federal Government. This view was corroborated by AjodoAdebanjoko (2017), who stated that the oil companies engage in 'Feel good projects' such as giving academic scholarships to some youths and building recreational centers in the communities to divert attention from the serious health and environmental impacts caused by their activities.

\section{The Niger Delta Conflict}

A conflict exists in a situation when facts, desires or fears pull or push participants against each other in divergence directions (Heitlier 2012). Once there is a conflict it is important to explore and understand how people respond to such situations, since unmanaged conflicts can result in several negative consequences (Ojiji, 2006; Colorado Conflict Consulting, 2007). The conflict in the Niger Delta has been attributed to many factors (Ikelegbe, 2005; Omofunma and Odia, 2009; Okoh, 2005; Ogaji, 2013; Ajodo-Adebanjoko, 2017):

(i) Marginalization and frustration among local communities

(ii) Clamour for more oil revenue

(iii) Environmental degradation resulting from oil extraction

(iv) Self-determination (Militancy)

(v) Resource control

(vi) Citing of community development projects

(vii) Conflict between elders and youths

(viii) Community disputes in associations

(ix) Chieftaincy tussle and

(x) Land disputes

Notwithstanding the fact that the conflict in the region has developed in a manner which suggests that different factors have accentuated the conflict at different times, it is difficult (if not impossible) to demonstrate in practice that one particular factor has had a greater exacerbating impact than another and that, that particular factor can be considered one of the explanatory variables for the conflict. This study seeks to:

i. Identify the causes/effects of conflicts in the Niger Delta

ii. Examine the impact of the existing conflict prevention and resolution measures/methods for the region in terms of adequacy, effectiveness and efficiency

iii. Determine adequate, efficient and effective methods of preventing and resolving conflicts

\section{Research Methodology}

A qualitative survey approach was adopted in this study and the first activity was to gather data in order to answer the following research questions:

Research Questions (RQ)

RQ1: Is lack of amenities the cause of conflicts in the Niger Delta?

RQ2: In what ways can these conflicts be prevented and resolved?

RQ3: What are the areas of needs in the oil producing communities?

To answer RQ1 and RQ2, the following hypotheses were tested:

$\mathrm{H}_{\mathrm{ol}}$ : Lack of amenities in the oil producing communities in the Niger Delta is not the cause of conflict in the area. $\mathrm{H}_{\mathrm{A} 1}$ : Lack of amenities in the oil producing communities in the Niger Delta is the cause of conflict in the area 
$\mathrm{H}_{\mathrm{o} 2}$ : Current methods of conflict resolution in the oil producing areas are not adequate

$\mathrm{H}_{\mathrm{A} 2}$ : Current methods of conflict resolution in the oil producing areas are adequate

In order to ensure a comprehensive analysis two sets of data were collected from:

(i) The indigenes of the oil producing communities

(ii) The major oil producing companies/oil based organizations operating in the oil producing communities.

The indigenes provided environmental data relating to the causes of conflicts, the effectiveness/efficiency of the current methods of conflict resolution and the specific needs of each community, while information relating to the projects executed in each community and the current methods used for conflict resolution were obtained from the oil firms and oil-based organizations. A questionnaire was designed and distributed with the aid of research assistants to the indigenes of the oil producing communities. To ensure that quality data was collected, the research assistants utilized were graduates and indigenes of the oil producing states where they were assigned to gather data. The questionnaire was designed to elicit data from the indigenes of the oil producing communities on the major causes of conflicts, the types of conflicts, the amenities that have been provided so far by Government and oil companies operating in their communities, current methods used for conflict resolution and the efficiency of such methods. Data was collected to gain an understanding of the views of the indigenes on the subject matter. The second set of data were collected using structured interviews of public relations representatives of the oil producing companies and the NDDC, and information on the projects sited so far, the criteria used, causes of conflicts and current methods of resolution were obtained.

\section{Questionnaire}

The first questionnaire was in three sections. The first section sought the demographic information of the respondents. The second section was designed to determine the causes of conflicts and some methods that had been adopted to resolve such conflicts while the third section was designed to elicit data on some of the amenities that have been provided and the needs of each community. The research assistants were given an initial briefing on the aim of the project and how to ensure that the questionnaires were properly filled and usable. A total of 3,700 questionnaires were distributed (20 per local government area) and 2,487 (67.21\%) were returned and used for the final analysis. Table 1 shows the states, local government areas visited and the questionnaires returned from each local government area.

Table 1: Data collected from States and local government areas visited

\begin{tabular}{|l|l|l|l|}
\hline S/N & State & No. of LGAs Visited & No. of Questionnaires Returned \\
\hline 1 & Abia & 17 & 237 \\
\hline 2 & Akwa Ibom & 31 & 394 \\
\hline 3. & Bayelsa & 08 & 98 \\
\hline 4 & Cross Rivers & 18 & 239 \\
\hline 5 & Delta & 25 & 324 \\
\hline 6. & Edo & 18 & 256 \\
\hline 7 & Imo & 27 & 382 \\
\hline 8 & Ondo & 18 & 270 \\
\hline 9 & Rivers & 23 & 287 \\
\hline \multicolumn{2}{|l|}{ Total } & $\mathbf{1 8 5}$ & $\mathbf{2 , 4 8 7}$ \\
\hline
\end{tabular}

\section{Population}

A population is the entire group whose characteristics are to be estimated, and a sample as a limited number of elements selected from the population which is representative of that population (Ndagi, 1999; Yomere and Agbonifoh, 1999). A random sampling method was used in this study. The sample population consisted of:

i. Youth Leaders from the oil producing communities

ii. Community Heads

iii. Women Leaders

iv. Staff of Local Government offices

v. Members of the oil producing communities 
A pre-test experiment of the questionnaire was conducted on 20 people randomly selected from two of the oil producing states. The suggestions made were effected before the final copies were produced and distributed.

\section{Data Analysis}

SPSS version 20 was used to analyze the data and to test the formulated hypothesis. First, a frequency analysis was performed. The results obtained from the study (Table 2) showed that the major causes of crisis in the Niger Delta Region are unemployment 876(35.2\%), inequitable distribution of resources/projects 588(23.6\%), environmental degradation 375(15.1\%), poverty and poor economic conditions 369(14.8\%) and human needs and frustration 233(9.4\%).

Table 2: Causes of Conflicts in the Niger Delta Region of Nigeria

\begin{tabular}{|l|l|l|}
\hline Causes of Conflicts & Frequency & Percent (\%) \\
\hline Unemployment & 876 & 35.2 \\
\hline Inequitable Distribution of Resources/Projects & 588 & 23.6 \\
\hline Environmental Degradation & 375 & 15.1 \\
\hline Government Policy & 123 & 4.9 \\
\hline Poverty and poor Economic Conditions & 369 & 14.8 \\
\hline Human Needs and Frustration & 233 & 9.4 \\
\hline
\end{tabular}

Table 3 shows the effects of conflicts with $1172(47.1 \%)$ of the respondents identifying 'lack of development' as a major effect of conflicts. Unrest 662(26.6\%) and criminality 577(23.2\%) are other effects of conflicts which may ultimately result in the re-location of companies and industries operating in the community 246(9.9\%).

Table 3: Effects of the Conflicts on the communities

\begin{tabular}{|c|l|l|}
\hline Effects of Conflict & Frequency & Valid Percent (\%) \\
\hline Unrest & 662 & 26.6 \\
\hline Lack of Development & 1172 & 47.1 \\
\hline Criminality & 577 & 23.2 \\
\hline Re-location of Companies/Industries & 246 & 9.9 \\
\hline
\end{tabular}

Another cause of conflicts is the awards of scholarship by the oil producing companies. $64.6 \%$ of the respondents are of the opinion that the companies do not award scholarships. Because of the level of unemployment and poverty in most oil producing communities, interventions such as scholarship awards can boost access to formal education (NBS, 2016).

In the bid to ascertain the claim that there are specific causes of conflict in the oil producing areas of the Niger Delta region, two hypotheses were formulated for the research, to measure the strength of relationships between variables. The hypotheses tested (Null Hypotheses) and their Alternatives presented in Table 4.

\section{Table 4: Hypotheses Tested and their Alternatives}

\begin{tabular}{|ll|}
\hline Null Hypothesis & Lack of amenities in the oil producing area of Niger Delta is not the cause of conflict in \\
$\mathrm{H}_{\mathrm{O} 1}:$ & the oil producing area of Niger Delta. \\
Alternative & Lack of amenities in the oil producing area of Niger Delta is the cause of conflict in the oil \\
Hypothesis $\mathrm{H}_{\mathrm{A} 1}:$ & producing area of Niger Delta. \\
\hline Null Hypothesis & Insufficient number of projects executed in the oil producing area of Niger Delta is not the \\
$\mathrm{H}_{\mathrm{O} 2}:$ & cause of conflict in the oil producing area of Niger Delta. \\
Alternative & Insufficient number of projects executed in the oil producing area of Niger Delta is the \\
Hypothesis $\mathrm{H}_{\mathrm{A} 2}:$ & cause of conflict in the oil producing area of Niger Delta. \\
\hline Null Hypothesis & Current methods of conflict resolution in the oil producing area of Niger Delta are not \\
$\mathrm{H}_{\mathrm{O} 3}:$ & adequate. \\
Alternative & Current methods of conflict resolution in the oil producing area of Niger Delta are \\
Hypothesis $\mathrm{H}_{\mathrm{A} 3}:$ & adequate.
\end{tabular}

\section{Hypothesis 1}

The summary of analysis of results as it relates to the test of hypothesis 1 . 
The Null Hypothesis $\left(\mathrm{H}_{\mathrm{o} 1}\right)$ states that: "Lack of amenities in the oil producing area of Niger Delta is not the cause of conflict in the oil producing area of Niger Delta."The hypothesis was tested with chi-square statistical method. The result is shown in Table 5.

Table 5: Results for Hypothesis 1

\begin{tabular}{|c|c|c|}
\hline & & $\begin{array}{c}\text { Has there been any conflict in } \\
\text { your Community? }\end{array}$ \\
\hline $\begin{array}{c}\text { What Amenities (that are presently lacking) would you require } \\
\text { for better living, in your Community? }\end{array}$ & $\begin{array}{c}\text { Pearson } \\
\text { Correlation }\end{array}$ & -.004 \\
Sig. (2-tailed) & $\mathrm{N}$ & .840 \\
& 2487 \\
\hline
\end{tabular}

Significant at a level of 0.05 (2-tailed)

Coefficient of determination is $0.840^{2}=0.7056$

This means that lack of amenities helps to explain about $71 \%$ of the variance of the cause of conflict when this variable is considered in isolation. However, the remaining $29 \%$ will be attributed to other factors other than lack of amenities. A t-test is used to test whether or not there is significant difference between the means of two groups. The t-critical value under 0.05 level of significance is 1.960 and the $t$-calculated (t-calc) is 11.0559 . Since the t-calculated (11.0559) is greater than t-critical (1.960), it means that the relationship is significant. The Null hypothesis was therefore rejected and the Alternate hypothesis which supports the claim that "Lack of amenities in the oil producing area of Niger Delta is the cause of conflict in the oil producing area of Niger Delta" was accepted.

\section{Hypothesis 2}

The summary of analysis of results as it relates to the test of hypothesis 2. The Null Hypothesis $\left(\mathrm{H}_{\mathrm{o} 2}\right)$ states that: Insufficient number of projects executed in the oil producing area of Niger Delta is not a cause of conflict in the oil producing area of Niger Delta.

The hypothesis was tested with chi-square statistical method. The result is shown in Table 6.

Table 6: Results for Hypothesis 2

\begin{tabular}{|l|l|l|}
\hline & & $\begin{array}{l}\text { Has there been any conflict in } \\
\text { your Community? }\end{array}$ \\
\hline \begin{tabular}{l|l} 
What other projects would you like to be added to make life \\
better for the people in your community?
\end{tabular} & $\begin{array}{l}\text { Cearson } \\
\text { Correlation } \\
\text { Sig. (2-tailed) } \\
\text { N }\end{array}$ & $\begin{array}{l}0.676 \\
2487\end{array}$ \\
\hline
\end{tabular}

Significant at a level of 0.05 (2-tailed)

Coefficient of determination is $0.676^{2}=0.4570$

This means that insufficient number of projects executed explains the $46 \%$ of the variance of the cause of conflict when this variable is considered in isolation. However, the remaining $54 \%$ can be attributed to other factors other than insufficient number of projects executed such as the distribution of the projects. The t-critical value at 0.05 level of significance is 1.960 and the $t$-calculated (t-calc) is 6.5512. Since the t-calculated (6.5512) is greater than t-critical (1.960), it means that the relationship is significant and not by chance. We therefore reject the null hypothesis and accept the Alternative hypothesis which supports the claim that "Insufficient number of projects executed in the oil producing region is a cause of conflict in the area. This is confirmed in a recent publication that the Ministry of Niger Delta completed only one project in its eight years of creation (Vanguard, 2016).

\section{Hypothesis 3}

The null hypothesis $\left(\mathrm{H}_{03}\right)$ states that "Current methods of conflict resolution in the oil producing areas of Niger Delta are not adequate." The hypothesis was first tested with simple frequency/percentage (\%) statistical method. The analysis of the null hypothesis result is shown in Tables 7 and 8. 
Table 7: What are the steps/measures that have been taken to prevent/resolve these conflicts in your Community?

\begin{tabular}{|l|l|l|}
\hline Conflict Resolution Method & Frequency & Percent (\%) \\
\hline Dialogue & 1627 & 65.4 \\
Government Intervention & 781 & 31.4 \\
Government \& Dialogue & 79 & 3.2 \\
Total & $\mathbf{2 4 8 7}$ & $\mathbf{1 0 0 . 0}$ \\
\hline
\end{tabular}

Table 8: How do you perceive the Effectiveness/Efficiency of these measures of prevention/resolution?

\begin{tabular}{|l|l|l|}
\hline $\begin{array}{l}\text { Perception of current methods of conflict } \\
\text { resolution }\end{array}$ & 664 & Pequency \\
\hline Adequate \& Effective & 699 & 26.7 \\
Inadequate \& Ineffective & 555 & 28.1 \\
Effective & 134 & 22.3 \\
Efficient & 435 & 5.4 \\
Neither Effective nor Efficient & $\mathbf{2 4 8 7}$ & 17.5 \\
Total & $\mathbf{1 0 0 . 0}$ \\
\hline
\end{tabular}

Table 7 shows three main methods currently used to prevent/resolve conflicts in the oil producing areas of Niger Delta: Dialogue 1627 (65.4\%) is the most frequently method used for conflict resolution. Other methods are Government Intervention 781(31.4\%); a combination of Government Intervention and Dialogue 79 (3.2).

However, to determine if the current methods of conflict resolution in the oil producing areas of Niger Delta are adequate, Table 8 which specifies the Effectiveness/Efficiency of the measures of prevention/resolution of conflict in the oil producing areas of Niger Delta was considered. 664 (26.7\%) of the respondents said the measures are adequate and effective; 669 (28.1\%) said they are Inadequate and Ineffective, 555 (22.3\%) said they are Effective, 134 (5.4\%) respondents said they are Efficient, while 435 (17.5\%) said they are Neither, Effective nor Efficient. It is significant to note from Table 8 that the percentage of respondents that feel the current measures used for conflict resolution are efficient was very low (5.4\%).

Hypothesis 3 was also tested with chi-square statistical method. The result is presented in Table 9.

Table 9: Efficiency of the current methods of conflict resolution

\begin{tabular}{|l|l|l|}
\hline & & $\begin{array}{l}\text { Has there been any conflict } \\
\text { in your Community? }\end{array}$ \\
\hline How do you perceive the Effectiveness/ Efficiency of & Pearson Correlation & .058 \\
these measures of prevention /resolution? & Sig. (2-tailed) & .045 \\
\cline { 2 - 3 } & $\mathrm{N}$ & 2487 \\
\cline { 2 - 3 }
\end{tabular}

Significant at a level of 0.05 (2-tailed)

Coefficient of determination is $0.045^{2}=0.002025$

A t-test was used to test whether or not there is significant difference between the effectiveness and efficiency of the current methods used for conflict resolution and the causes of conflicts. The t-critical table value under 0.05 obtained is 3.182 while $t$-calculated (t-calc) is 0.0780. Since the t-calculated (0.0780) is less than t-critical (3.182), it means that the relationship is not significant. We therefore accept the Null Hypothesis $\left(\mathrm{H}_{\mathrm{o} 3}\right)$ that supports the claim that the: "Current methods of conflict resolution in the oil producing area of Niger Delta are not adequate." This shows that dialogue may not be the best option for resolving conflicts in the Niger Delta.

\section{Conclusion}

Based on the findings of the study, the researchers conclude that lack of amenities, youth unemployment, environmental degradation and insufficient projects executed in the Niger Delta region are the major factors that cause and influence violent conflicts in the Niger Delta region of Nigeria. From the study the researchers also conclude that the current methods of conflict resolution/prevention in the oil producing areas of the Niger Delta are inadequate and ineffective. 
Dialogue/negotiation was identified as the most frequently used method of conflict resolution/prevention in the oil producing area of the Niger Delta. However, very few respondents considered this method of conflict resolution to be effective and efficient. The study has shown that the provision and maintenance of infrastructure such good roads, hospitals, electricity, schools, portable water supply plus reduced environmental pollution by the activities of oil exploration will reduce conflicts in the Niger Delta region of Nigeria. The outcome of these findings is used to develop a neuro-fuzzy based expert system to monitor and predict conflict situations in the Niger Delta states of Nigeria.

\section{Acknowledgements}

The authors acknowledge the management of the National Information Technology Development Agency (NITDA), Abuja, Nigeria for the research grant to support the project.

\section{References}

Ajodo-Adebanjoko, A. (2017). "Towards ending conflict and insecurity in the Niger Delta region", Report from African Centre for the Constructive Resolution of Disputes (ACCORD), Retrieved 22-03-18 online from: http://www.accord.org.za/ajcr-issues/towards-ending-conflict-insecurity-niger-delta-region/

Colorado Conflict Consulting (2007). "Consequences of Conflict", Retrieved online from http://www.coloradoconflict.com

Heitlier, S. (2012). What makes Conflict? How are conflicts resolved? Psychology Today.

Ikelegbe, A. (2006): Youths, Militants and self Determination in the Niger Delta. Benin: Aprophy Publishers.

Ikelegbe, A. (2005), "The economy of conflict in the oil rich Niger Delta region of Nigeria." Nordic Journal of African Studies, Vol. 14, No. 2, pp. 208-234.

Imobighe, T. (ed.) (2003). Civil Society and Ethnic Conflict Management in Nigeria, Spectrum publishers, Ibadan.

National Bureau of Statistics (NBS) (2016) Unemployment and underemployment watch, $1^{\text {st }}$ quarter of 2016, online at: http://www.nigerianstat.gov.ng/library

Ndagi, J.O. (1999). The Essentials of Research Methodology for Educators, Revised Edition, University Press Plc, Ibadan, Nigeria.

Obi, C. (2009). "Nigeria's Niger Delta: Understanding the Complex Drivers of Violent Oil-Related Conflict." Africa Development. Council for the Development of Social Science Research in Africa. Vol. 1014, No. 2, pp. 103-128. (ISSN 0850-3907)

Ogaji, O. J. (2013). The viability of applying alternative dispute resolution processes in the Niger Delta conflict, A Ph.D. Theses at University of Warwick, UK, Retrieved 20-10-2015 online from http://go.warwick.ac.uk/wrap/60366

Ojiji, O. (2006). Conflict Handling styles. Introduction to Peace and Conflict Studies in West Africa. Spectrum Books, Ibadan.

Okoh, R. (2005) "Conflict Management in the Niger Delta Region of Nigeria- A Participatory Approach", African Journal of Conflict Resolution (AJCR), Issue 1, Retrieved online from http://www.accord.org.za/ajcrissues/conflict-management-in-the-niger-delta-region-of-nigeria/.

Omeje, K. (2005). "Oil conflict in Nigeria: Contending issues and perspectives of the local Niger Delta people." New Political Economy, Vol. 10, No. 3, pp. 321-334.

Omofonmwan, S. and Odia, L. (2009). "Oil Exploitation and Conflict in the Niger-Delta Region of Nigeria." Journal of Hum. Ecology. , Vol. 26, No. 1, pp. 25-30.

Omotoso, T. (2013). “Transnational Oil Corporations' Operations and Environmental Degradation in Nigeria, 1956-2010." Continental J. Arts and Humanities, Vol. 5, No. 1, P. 20 - 33.

Vanguard Newspapers (2016, August 9). 8yrs After Creation, N-Delta Ministry Completes Only One Project Minister. Vanguard Newspapers. Retrieved from http://www.vanguardngr.com/2016/08/8yrs-creation-ndelta-ministry-completes-one-project-minister/

Yomere, G. O. and Agbonifoh, B. A. (1999). Research Methodology in Social Sciences and Education. Uniben Press, Benin City. Nigeria. 